\title{
A rare cause in etiology of left atrial mass: metastatic testicular germ cell tumor
}

\author{
Serhat Huseyin ${ }^{1}$, Volkan Yüksel ${ }^{1}$, Ahmet Okyay², ilhan Hacıbekiroğlu ${ }^{3}$, Ebru Tastekin ${ }^{2}$, \\ Mustafa Yılmaztepe ${ }^{4}$, Gökay Taylan ${ }^{4}$, Suat Canbaz ${ }^{1}$, İrfan Çiçin ${ }^{3}$ \\ ${ }^{1}$ Department of Cardiovascular Surgery, Trakya University Faculty of Medicine, Edirne, Turkey \\ 2Department of Pathology, Trakya University Faculty of Medicine, Edirne, Turkey \\ ${ }^{3}$ Trakya University Medical Oncology Department, Edirne, Turkey \\ ${ }^{4}$ Trakya University Cardiology Department, Edirne, Turkey \\ Kardiochirurgia i Torakochirurgia Polska 2016; 13 (1): 45-48
}

\begin{abstract}
Although intracardiac metastasis of germ cell tumors is rare, it can be localized in the right or left heart by disseminating spread and give their cardiac symptoms depending on the location of metastatic mass. We present a 38-year-old male patient with a preliminary diagnosis of testicular tumor who was followed by the medical oncology clinic with cerebrovascular event and heart failure symptoms.
\end{abstract}

Key words: germ cell tumor, intracardiac metastasis, surgery.

\section{Introduction}

Testis tumors are rare, but it is the most common solid tumor in men under 45 years of age. They represent 1-2\% of all malignant tumors in men [1]. Germ cell tumors account for almost $90 \%$ of all testis tumors. Although intracardiac metastases of testicular germ cell tumors occur rarely in clinics, they may lead to the congestive heart failure, paradoxical systemic emboli and vena cava superior syndrome with disseminated involvement of the right or left heart [2-5]. Metastatic tumors of the heart are seen more frequently when compared to primary tumors. Lung cancer and breast cancer are the most frequent tumors that lead to metastases to the heart [3]. Autopsy series done by Bredael et al. [6] revealed that the most common metastatic sites for testicular carcinoma are the lungs, liver, brain, and bone whereas intracardiac metastases are found in less than $1 \%$ of patients. Here, we report a patient with a prediagnosis of testis tumor and developed symptoms of the cerebrovascular accident and heart failure.

\section{Case report}

A 38-year-old man admitted to hospital with the complaint of swelling in the left testis for the last 3 months.

\section{Streszczenie}

Przerzuty wewnątrzsercowe nowotworów germinalnych są rzadkie, niemniej jednak zdarzają się przypadki rozsiania tych nowotworów do prawego lub lewego serca, powodujące objawy kardiologiczne zależne od umiejscowienia nowotworu. Celem pracy jest przedstawienie przypadku 38-letniego pacjenta ze wstępną diagnozą nowotworu jądra, który został przyjęty do kliniki onkologicznej z objawami zdarzenia mózgowo-naczyniowego i niewydolności serca.

Słowa kluczowe: nowotwór germinalny, przerzut wewnątrzsercowy, chirurgia.

Scrotal ultrasonography revealed heterogeneous and hypoechogenic solid mass lesion in the left testis with $9 \times 6 \mathrm{~cm}$ dimensions. Normal testicular tissue was not observed and it was considered to be testicular tumor.

Thoracic computed tomography (CT) showed many bilateral parenchymal metastatic lesions in the lungs, the biggest one was $7 \times 9 \times 11 \mathrm{~cm}$ in dimensions and located in the left upper paramediastinal region (Fig. 1). Serum $\beta$-HCG was $89.7 \mathrm{IU} / \mathrm{ml}$ and AFP was $1050 \mathrm{ng} / \mathrm{dl}$.

While the patient had been followed up by the medical oncology department, a cerebrovascular accident (CVA) developed and symptoms of NYHA class 4 heart failure were detected. Then, an echocardiography was performed. Echocardiography revealed a mass attached to the mitral valve with $18 \times 52 \mathrm{~mm}$ in dimensions and filling two thirds of the left atrium. It was tufted with irregular borders and prolapsing into the left ventricle (Fig. 2). The patient underwent the surgery following our examination.

Under general anesthesia, after median sternotomy, cardiopulmonary bypass was started with bicaval cannulation. Left atriotomy was performed following cross clamp placement. Left atrium was explored and a $5 \times 3 \mathrm{~cm}$ pe- 


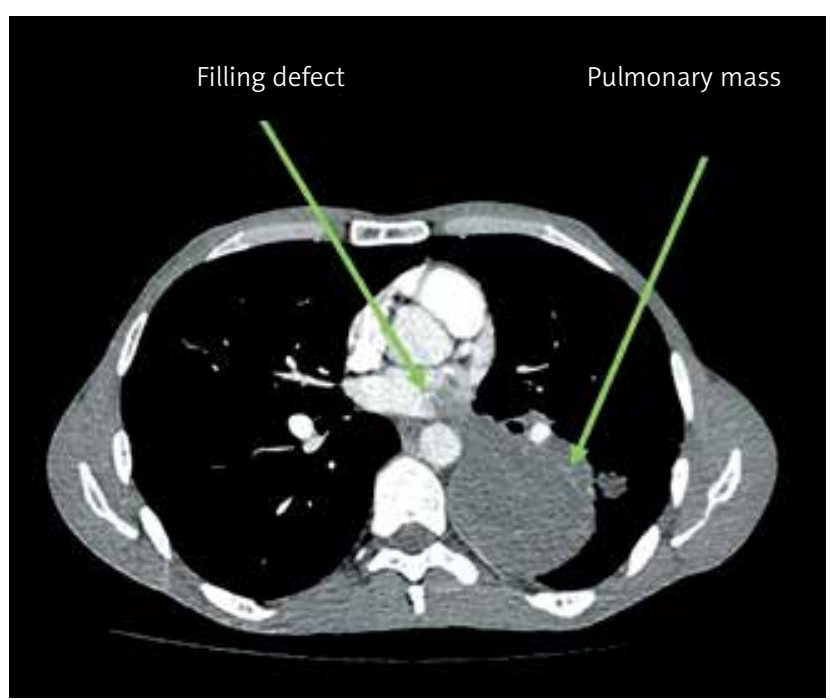

Fig. 1. Computed tomography of thorax shows extension of metastatic mass in the lung to the left atrium via left lower pulmonary vein and the filling defect created by it

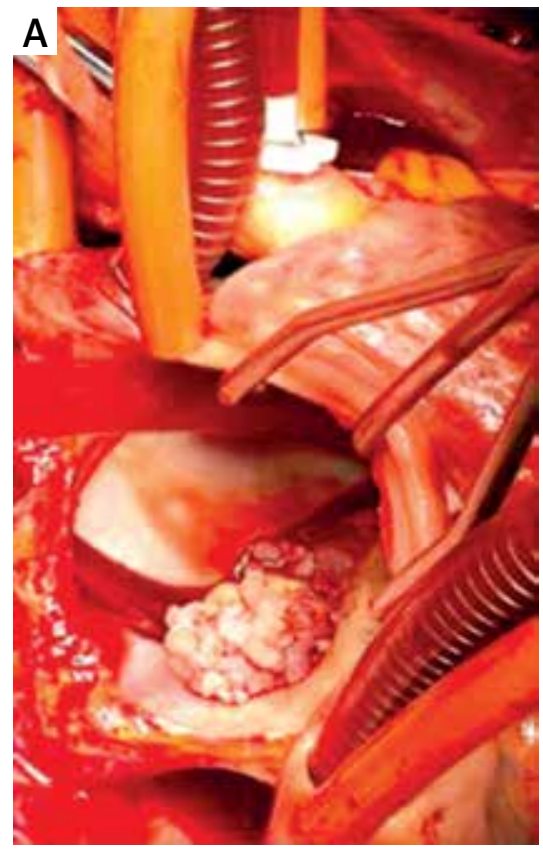

B

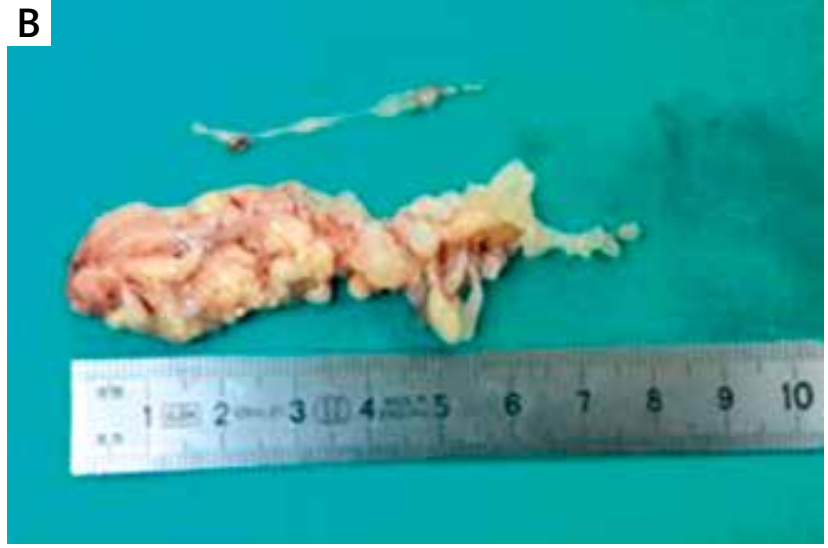

Fig. 3. A) Intraoperative appearance of the left atrial mass. B) Macroscopic appearance of the mass after excision

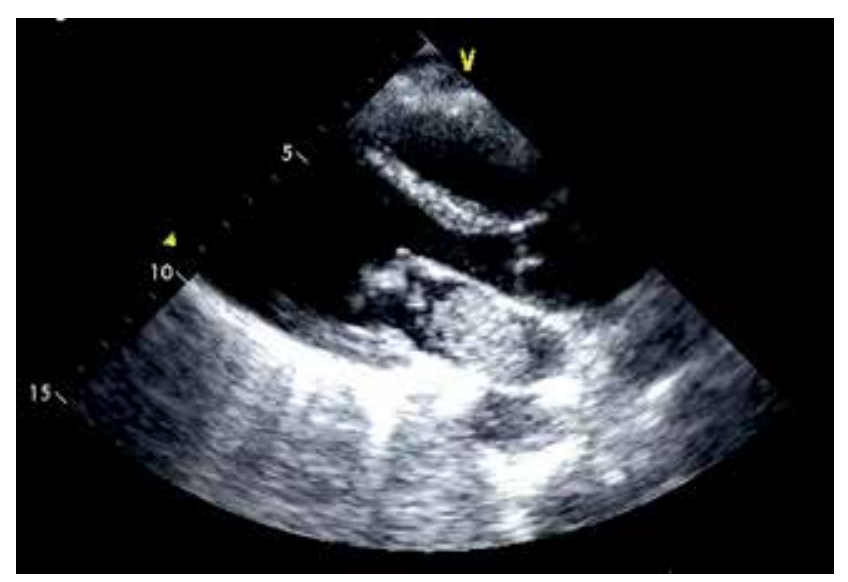

Fig. 2. Mass image in the left atrium by echocardiography

dunculated fragile mass was seen in the left atrium. It was free of the atrial wall and mitral valve. The pedicle was extending to the left lower pulmonary vein and was probably a part of metastatic mass in the left lung. The mass was excised totally (Fig. 3). The left atrial space was irrigated by saline after excision and there was no residual mass. There was a slight mitral valve insufficiency which required no additional intervention. Cardiopulmonary bypass was terminated without any complication or problem.

The patient was taken to the postoperative intensive care unit for 1 day and discharged on the $6^{\text {th }}$ postoperative day. He was taken to the medical oncology department for therapy. Symptoms of the patient declined to NYHA class 1 postoperatively. Postoperative echocardiography revealed first degree mitral insufficiency and no residual mass.

Pathologic examination of the left atrial mass with a large amount of polypoid tissue revealed hypocellular mesenchymal tissue consistent with a non-seminomatous germ cell tumor metastasis. Microscopically teratoid glandular and ductular structures lined by columnar or squamous epithelial cells were seen in an edematous and hemorrhagic fibrous stroma. Epithelial areas were very scanty and focal. The small foci of choriocarcinoma component were located in hemorrhagic areas. Immunohistochemically, while teratoid areas were stained with pankeratin, choriocarcinoma areas were stained with HCG (Fig. 4).

Metastatic testicular germ cell tumor was diagnosed and BEP (bleomycin, etoposide, cisplatin) chemotherapy protocol was started 15 days after the surgery. The patient did not have any problem in wound healing during the follow-up. The thoracic CT at sixth month's control showed regression in the pulmonary mass and no recurrence in the cardiac cavity (Fig. 5).

\section{Discussion}

Testicular tumors are among the tumors with the best therapy success and the longest survival. Patients have the chance of cure even in the advanced stages [7]. Five-year survival rate is $90 \%$ without distant metastases and $60 \%$ with distant metastases [8].

Cardiac metastases are rare in malignant tumors and their incidence ranged between $1.5 \%$ and $18.3 \%$ in various 

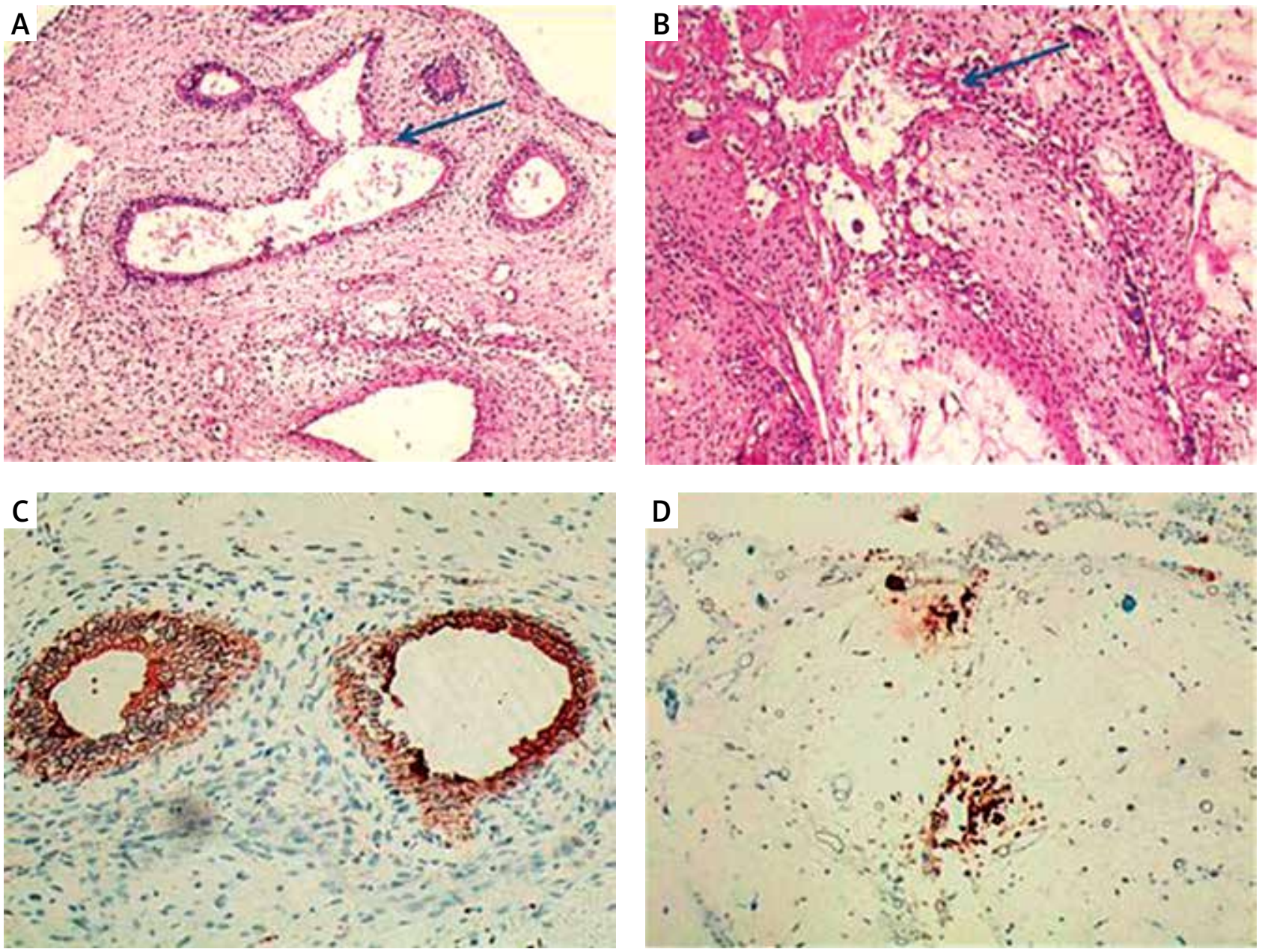

Fig. 4. Pathological examination. A) Teratomatous (blue arrow). B) Choriocarcinomatous (blue arrow) components were detected in tumor. C) Immunohistochemically teratomatous component was stained with pan-keratine. D) Choriocarcinomatous component was stained with HCG antibodies (x100)

reports [1]. Based on autopsy reports of 1029 patients with malignancy, the most frequent metastasis occurs in pericardium and the most frequently metastasizing tumor is lung cancer which is followed by lymphoma, breast cancer and esophagus cancer [9].

The most common sites of metastasis in testis tumors are paraaortic lymph nodes, mediastinal lymph nodes, lungs and supraclavicular fossa. Testicular germ cell tumors rarely spread to the heart. The incidence of metastatic involvement of cardiac endothelium and valvular surface due to testis tumors is $3.8 \%$ and it is considered that hematogenous spread via vena cava inferior is the main route [10]. Cardiac metastasis can be via hematogenous route, lymphatic route or both. Lymphatic spread follows ductus thoracicus pathway to the heart [11]. Hematogenous spread may involve lungs, liver, bones, brain and heart.

Chest pain, newly developed effusion, symptoms of tamponade, increase in the dimensions of the heart, new murmurs, new electrocardiography (ECG) changes and unexplained cardiac failure may point out to cardiac metastasis in patients with a neoplastic disease. In addition, dizziness,

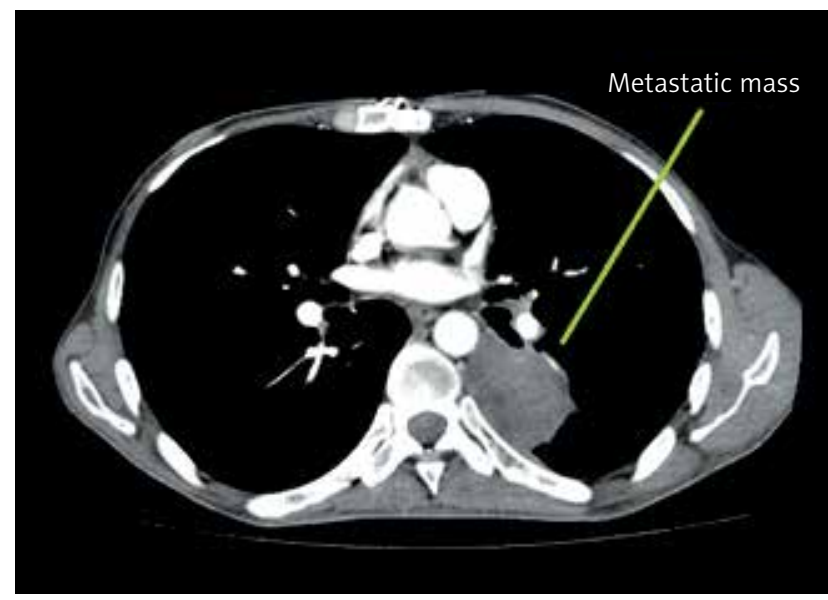

Fig. 5. Computed tomography shows regression of metastatic mass in the lung and no filling defect in the cardiac cavity

hypotension, loss of consciousness, and seizure may indicate embolization to the brain and intracardiac mass [12].

In literature, cases of right atrial mass and right heart failure are more common, but our case showed left atrial 
mass and symptoms of left heart failure. Excision of tumor mass led to dramatic regression of clinical symptoms. There was no recurrence at the postoperative $6^{\text {th }}$ month follow-up visit.

In conclusion, cardiac output can be corrected by radical cardiac surgery in malignant germ cell testicular tumors with cardiac involvement. Although cardiac involvement has been related to short survival and worse prognosis, tumor type, tumor marker levels and the number of metastatic sites may affect prognosis [13]. The resulting clinical status in this patient encouraged us to conclude that a patient with disseminated cancer can be operated for treatment purposes. Developments in imaging techniques and surgical methods enable curative treatment choices in such patients during metastatic stages.

\section{Disclosure}

Authors report no conflict of interest.

\section{References}

1. Fishman AD, Hoffman A, Volterra F, Frymus M, Gentilluci M. Intracaval and intracardiac metastatic nonseminomatous germ cell tumor: a rare cause of hemolytic anemia and thrombocytopenia. Cancer Invest 2002; 20: 996-1001.

2. Jonjev ZS, Rajić J, Majin M, Donat D. Intracardiac metastasis from germ cell testicular tumor. Herz 2012; 37: 709-711.
3. Stefka J, Cleveland JC, Lucia MS, Singh M. Sarcomatoid intracardiac metastasis of a testicular germ cell tumor closely resembling primary cardiac sarcoma. Hum Pathol 2003; 34: 1074-1077.

4. May M, Finkbeiner Y, Gunia S, Seehafer M, Knörig J, Hetzer R. Metastasizing testicular germ-cell tumor with infiltration of the right heart: indication for primary metastasectomy. Heart Vessels 2006; 21: 63-65.

5. Fishman AD, Hoffman A, Volterra F, Frymus M, Gentilluci M. Intracaval and intracardiac metastatic nonseminomatous germ cell tumor: a rare cause of hemolytic anemia and thrombocytopenia. Cancer Invest 2002; 20: 996-1001.

6. Bredael JJ, Vugrin D, Whitmore WF Jr. Autopsy findings in 154 patients with germ cell tumors of the testis. Cancer 1982; 50: 548-551.

7. Gori S, Porrozzi S, Roila F, Gatta G, De Giorgi U, Marangolo M. Germ cell tumours of the testis. Crit Rev Oncol Hematol 2005; 53: 141-164.

8. Dickman PW, Hakulinen T, Luostarinen T, Pukkala E, Sankila R, Söderman B, Teppo L. Survival of cancer patients in Finland 1955-1994. Acta Oncol 1999; 38 Suppl 12: 1-103.

9. Johnson DE, Appelt G, Samuels ML, Luna M. Metastases from testicular carcinoma. Study of 78 autopsied cases. Urology 1976; 8: 234-239.

10. Klatt EC, Heitz DR. Cardiac metastases. Cancer 1990; 65: 1456-1459.

11. Taghavi F, Markar S, Williams M, Large S. Intra-cardiac metastasis from testicular non-seminoma germ cell tumour; to resect or not to resect. Interact Cardiovasc Thorac Surg 2010; 11: 843-845.

12. Hall RJ, Colley DA, McAllister HA Jr, Frazier OH, O'Rourke RA. Neoplastic heart disease. In: Hurst's the Heart. Fuster V, Alexander RW, O'Rourke RA, Robert R, King SB III, Nash IS, Prystowsky EN. $11^{\text {th }}$ ed. McGraw Hill Publishers, New York 2004; 2081-2096.

13. International Germ Cell Consensus Classification: a prognostic factorbased staging system for metastatic germ cell cancers. International Germ Cell Cancer Collaborative Group. J Clin Oncol 1997; 15: 594-603. 